\title{
ANALISIS KEBERHASILAN USAHA PAKAN TERNAK CV. MUDA JAYA MANDIRI DITINJAU DARI ASPEK PEMASARAN DAN KEWIRAUSAHAAN
}

\author{
Iskandar \\ Sekolah Tinggi Ilmu Ekonomi Riau \\ E-mail: iskandarbis86@gmail.com
}

\begin{abstract}
This research was conducted at CV. Muda Jaya Mandiri, located in Teratak Buluh, Kampar Regency. The purpose of this study was to determine the magnitude of the effect of marketing and entrepreneurial aspects on the success rate of animal feed businesses in the CV. Muda Jaya Mandiri. To achieve these objectives, a study was conducted using samples from all customers of CV. Muda Jaya Mandiri numbered 54 people, using a simple random method (incidental random sampling). The data analysis method that the author uses in this study is an analysis using descriptive methods, namely by describing all the circumstances that occur. Based on the results of the study obtained positive responses from respondents. This shows that there is a positive influence on the marketing aspects and entrepreneurship aspects of the success of the animal feed business on the CV. Muda Jaya Mandiri. The recommendation that the writer can propose is to further increase animal feed sales, which company should CV. Muda Jaya Mandiri to put more emphasis on marketing aspects, namely the price variable and the distribution variable. To increase sales of animal feed business, the price factor should be more competitive with competing animal feed products, which are factory feed. In addition, the distribution channel is very active in increasing sales of animal feed, it is expected that the company will market its products outside the region so that CV Muda Jaya Mandiri can be better known by others.
\end{abstract}

Keywords: Aspek Pemasaran, Kewirausahaan, Keberhasilan usaha

\section{A. PENDAHULUAN}

Terjadinya ketidaksetabilan ekonomi memberikan gambaran yang jelas adanya ketimpangan pendapatan ditengah masyarakat. Hal ini mengajarkan bahwa pengelolaan ekonomi tidak boleh diserahkan sepenuhnya pada usaha-usaha skala besar. Strategi pembangunan ekonomi yang diterapkan pada usaha masa lalu yang lebih mengutamakan pertumbuhan dengan mengeyampingkan pemerataan ternyata hanya menghasilkan ekonomi yang rapuh.

Saat ini pemerintah mulai memberikan peran yang besar bagi perkembangan perekonomian kerakyatan dengan menekankan pentingnya peningkatan kualitas, produktivitas dan daya saing ekonomi kerakyatan. Caranya dengan memberikan peranan yang lebih besar kepada usaha kecil, menengah dan koperasi yang telah terbukti memiliki kemandirian dan ketahanan yang lebih besar dalam menghadapi krisis ekonomi.

Pembanguan industri kecil bukan saja penting sebagai langkah pemerataan hasilhasil pembangunan, tetapi juga mengembangkan sistem ekonomi kerakyatan yang bertumpu pada mekanisme pasar yang berkeadilan berbasis pada sumber daya alam dan sumber daya manusia yang produktif, mandiri, maju, berdaya saing, berwawasan lingkungan, dan berkelanjutan.

Pengembangan ekonomi kerakyatan yang diterapkan dapat memberikan kontribusi yang signifikan terhadap upaya-upaya penanggulangan masalah ekonomi dan sosial yang dihadapi oleh Negara-negara berkembang seperti tingginya tingkat kemiskinan, besarnya jumlah pengangguran, ketimpangan distribusi pendapatan, peroses pembangunan yang tidak merata serta masalah-masalah urbanisasi dengan segala efek-efek negatifnya.

Jiwa kewirausahaan sangat diperlukan dalam kehidupan era global yang penuh persaingan ketat dimana dalam persaingan tersebut diperlukan sikap-sikap ulet dan tangguh, kreatif, inovatif, dinamis, produktif, beretos kerja keras, efesien, disiplin, visioner, antisipatif maupun menciptakan peluang baru, berani mengambil keputusan yang tepat sehingga memperkecil resiko, jujur dan terpercaya.

Saat ini keberadaan usaha pakan ternak di Kab. Kampar mempunyai kontribusi dalam menunjang pembangunan ekonomi daerah maupun ekonomi nasional, 
mengantisipasi dampak globalisasi ekonomi, keterbatasan kesempatan kerja, dan peningkatan pendapatan. Memperhatikan peranan usaha pakan ternak, maka selayaknya pakan ternak sebaiknya dikelola oleh para entrepreneur yang kreatif dan inovatif sehingga memiliki keunggulan komperatif dan kompetitif.

\section{Pengertian Keberhasilan Usaha}

Perusahaan atau organisasi manapun, pasti ingin mencapai sasaran yang telah ditetapkan. Dengan kata lain, mereka ingin mencapai keberhasilan usaha. Salah satu langkah untuk mengukur keberhasilan itu adalah melakukan penilaian kinerja. Penilaian kinerja memang penting, sebab selain digunakan sebagai ukuran keberhasilan suatu organisasi dalam kurun waktu tertentu, ia dapat juga jadi masukan untuk perbaikan atau peningkatan kinerja organisasi selanjutnya.

Finansial (profitabilitas) memang dianggap sebagai aspek utama dalam mengukur kinerja perusahaan, namun belum memadai untuk menjelaskan efektifitas perusahaan secara umum sehingga perlu ada kelengkapan kinerja dari aspek lain. Pandangan ini dikemukakan antara lain oleh Kevitt \& Lawton dan Dess (dalam manajemen \& Usahawan 1997). Menurut Dess pengukuran kinerja hanya dengan menekankan aspek keuangan punya kelemahan, misalnya tak mampu mengukur kinerja harta-harta tak tampak (intangible assets) dan harta-harta intelektual (sumber daya manusia) perusahaan.

Kaplan dan Norton mengusulkan pengukuran kinerja bisnis dengan balance scorecard. Balance Secorecard adalah metode penilaian kinerja perusahaan yang mengembangkan empat prespektif pengukuran, yakni perspektif keuangan, pelanggan, proses bisnis internal, dan proses belajar dan pertumbuhan. Meskipun teknik pengukuran kinerja balance scorecard merupakan cara yang paling komperhensif, pelaksanaannya sulit karena melibatkan banyak pihak sehingga biayanya mahal dan makan waktu lama (Dwi Riyanti, 2003: 26)

Eko dan Bisnis (Riau Economics and Business Reviewe) Volume 10, Nomor 4, 27 Desember 2019
Menurut Rue dan Byars keberhasilan usaha dapat didefinisikan sebagai tingkat pencapaian hasil atau pencapaian tujuan organisasi (Dwi Riyanti, 2003: 25).

Karena jenis usaha yang dipilih dalam penelitian ini adalah jenis usaha industry yang memproduksi barang jadi, maka kegiatan produksi menjadi tolok ukur dalam keberhasilan usaha. Keberhasilan usaha dalam penelitian ini adalah tingkat kepuasan akan keberhasilan usaha menurut persepsi dari pemilik usaha pakan ternak.

Menurut (Dwi Riyanti, 2003: 28), kriteria yang cukup signifikan menentukan keberhasilan usaha dapat dilihat dari :

1. Peningkatan dalam akumulasi modal atau peningkatan modal.

2. Jumlah produksi

3. Perluasan usaha

4. Perbaikan sarana fisik.

\section{Strategi Bauran Pemasaran (Marketing Mix)}

Untuk memberi kejelasan mengenai bauran pemasaran ini dikemukakan beberapa pengertian dari marketing mix itu sendiri. Marketing mix adalah bermacam kebijaksanaan pemasaran yang dipergunakan untuk merebut pembeli sasaran, secara ringkas dapat digolongkan menjadi empat yaitu :

1. Kebijaksanaan produk

2. Kebijaksanaan harga

3. Kebijaksanaan distribusi

4.Kebijaksanaan Promosi (Sutejo Siswanto, 1996 ;13)

Pendapat lain mengatakan, marketing mix itu adalah kelompok variabel yang dapat dikendalikan dan dapat dipergunakan oleh perusahaan yang bersangkutan untuk mempengaruhi reaksi pembeli. (Winardi, $2000 ; 319$ )

Dari kedua pengertian di atas dapat diambil kesimpulan bahwa pada prinsipnya marketing mix itu bertujuan untuk mempengaruhi pasar, konsumen dan permintaan juga merebut pembeli sasaran dalam satu persaingan melalui empat

P.ISSN: 1410-7988 E.ISSN: 2614-123X 
variabel yang merupakan inti dari sistem pemasaran perusahan yaitu : produk, harga, promosi dan distribusi.

1. Produk

2. Harga

3. Distribusi

4. Promosi

\section{Pengertian Kewirausahaan}

Kewirausahaan yang sering dikenal dengan sebutan entrepreneurship berasal dari bahasan Prancis yang diterjemahkan secara harafiah adalah perantara. Secara lebih luas kewirausahaan didefinisikan sebagai proses penciptaan sesuatu yang berbeda nilainya dengan menggunakan usaha dan waktu yang diperlukan, memikul resiko finansial, psikologi dan sosial yang menyertainya serta menerima balas jasa moneter dan kepuasan pribadi. Namun demikian, istilah kewirausahaan dapat pula diartikan sebagai sikap dan prilaku mandiri yang mampu memadukan unsur cipta, rasa dan karsa serta karya atau mampu menggabungkan unsur kreativitas, tantangan, kerja keras dan kepuasan untuk mencapai prestasi maksimal sehingga dapat memberikan nilai tambah maksimal terhadap jasa, barang maupun pelayanan yang dihasilkan dengan mangindahkan sendi-sendi kehidupan masyarakat.

Meskipun sampai sekarang ini belum ada terminology yang persis sama tentang pengertian kewirausahaan (entrepreneurship), akan tetapi pada umumnya memiliki hakekat yang hampir sama yaitu merujuk pada sifat, watak dan ciri-ciri pada seseorang yang mempunyai kemauan keras untuk mewujudkan gagasan inovatif ke dalam dunia usaha yang nyata dan dapat mengembangkan dengan teguh.

Menurut Soeharto Prawirokusuma, istilah kewirausahaan berasal dari terjemahan entrepreneurship, yang dapat diartikan sebagai "the blackbone of economiy, yaitu syaraf pusat perekonomian atau sebagai tailbone of economy", pengendalian perekonomian suatu bangsa.

Secara Epistimologi, kewirausahaan merupakan nilai yang diperlukan untuk

Eko dan Bisnis (Riau Economics and Business Reviewe) Volume 10, Nomor 4, 27 Desember 2019 memulai suatu usaha (start-up phase) atau suatu proses dalam mengerjakan suatu yang baru (creative) dan sesuatu yang berbeda (innovative) (Suryana, 2003: 10)

Kewirausahaan adalah suatu
membangun suatu nilai dari sesuatu yang sebelumnya tidak mempunyai nilai, ia berusaha mencapai peluang-peluang berdasarkan sumberdaya-sumberdaya atas masing-masing sumberdaya yang dimilikinya. Ia memerlukan suatu visi dan kesabaran serta komitmen untuk mengajak orang lain untuk mencapai visi tersebut. Ia juga memerlukan suatu kesediaan untuk mengambil risiko yang diperhitungkan.

Kewirausahaan disebut sebagai suatu peroses kreatifitas yang desdruktif. Dimana wirausaha secara terus menerus berupaya mengganti atau memusnahkan produk yang ada atau metode produksi dengan sesuatu yang baru.

Menurut (Thomas W. Zimmerer, 1996: 51), kewirausahaan adalah "applying creativity and innovation to slove the problems and to exploit opportunities that people face everyday".

Kewirausahaan adalah sebuah proses dinamis dalam menciptakan tambahan kekyaan. Kekayaan dihasilkan oleh individu yang menanggung resiko utama dalam hal modal, waktu dan/atau komitmen karir yang menyediakan nilai bagi beberapa produk atau jasa. Produk atau jasa mungkin dapat terlihat unik ataupun mungkin tidak, namun dengan berbagai cara nilai akan dihasilkan oleh seorang pengusaha dengan menerima dan menempatkan keterampilan dan sumber daya yang dibutuhkan ini. (Robert D.Hisrich, dkk 2008 : 9)

Sementara menurut lampiran Intruksi Presiden Nomor 4 Tahun 1995 Tanggal 30 Juni 1995 tentang Gerakan Nasional Memasyarakatkan dan membudayakan Kewirausahaan pada Point I (Susilo Proyono, 2004: 16) disebutkan : "Kewirausahaan adalah kemampuan seseorang dalam menangani usaha dan atau kegiatan yang mengarah pada upaya

P.ISSN: 1410-7988 E.ISSN: 2614-123X 
mencari, menciptakan, menetapkan cara kerja, teknologi dan produk baru dengan meningkatkan efisiensi dalam rangka memberikan pelayanan yang lebih baik dan atau memperoleh keuntungan yang lebih besar.

Selain itu, kewirausahaan adalah semangat, perilaku dan kemampuan untuk memberikan tanggapan yang positf terhadap peluang. Memperoleh keuntungan untuk diri sendiri atau pelayanan yang lebih baik pada pelanggan/ masyarakat, dengan selalu berusaha mencari dan melayani langganan lebih banyak dan lebih baik serta menciptakan dan menyediakan produk yang lebih bermanfaat dan menerapkan cara kerja yang lebih efesien melalui keberanian mengambil resiko, kreatifitas dan inovasi serta kemampuan manajemen. (Salim Siagian, 1996: 6).

Dari pandangan para ahli diatas dapat disimpulkan bahwa kewirausahaan (entrepreneurship) adalah suatu kemampuan dalam berfikir kreatif dan berprilaku inovatif yang dijadikan dasar, sumberdaya, tenaga penggerak, tujuan siasat, kiat dan proses dalam menghadapi tantangan hidup.

Istilah entrepreneurship merupakan fenomena individu yang merupakan karateristik yang dimiliki oleh seseorang yang menjalankan sesuatu usaha untuk dirinya sendiri. Dengan demikian entrepreneurship lebih identik dengan persoalan usaha kecil. Sedangkan entrepreneurship merupakan karakteristik yang dimiliki seseorang yang bukan bekerja untuk dirinya sendiri, akan tetapi bekerja untuk orang lain atau bekerja pada perusahaan besar. Namun demikian entrepreneurship dapat terjadi pada tingkat perusahaan induk (corporate), unit bisnis, atau fungsional dengan tujuan memperbaiki posisi daya saing dan kinerja keuangan perusahaan.

Interprenuer adalah sebutan bagi para enterprenuer yang bekerja untuk institusi. Pada hakekatnya sama dengan enterprenuer berbeda bila entrepreneur bekerja dan hasilnya untuk mereka sendiri.

Eko dan Bisnis (Riau Economics and Business Reviewe) Volume 10, Nomor 4, 27 Desember 2019
Sedangkan intraprenuer bekerja dan hasilnya digunakan untuk kemajuan lembaga/ instansi dimana mereka bekerja (Suwandi, 2000: 56).

Setiap individu pada dasarnya mempunyai jiwa kewirausahaan, tetapi seseorang atau beberapa orang cendrung lebih kreatif, agresif dn lebih mempunyai determinasi daripada yang lain. Dengan meramu bermacam-macam sumber daya, berani mengambil resiko. Membangun usaha adalah benar-benar mereka yang mempunyai jiwa kewirausahaan (Soeharto Prawirokusumo, 1999: 56).

Wirausaha dengan jiwa kewirausahaan yang dimilikinya merupakan modal dasar untuk menghasilkan output berupa kinerja atau keberhasilan usaha. Jiwa kewirausahaan sangat diperlukan dalam kehidupan era global yang penuh persaingan yang ketat dan penuh ketidakpastian, dimana dalam persaingan tersebut diperlukan sikap ulet, dan tangguh, kreatif dan inovatif, dinamis, produktif, etos kerja keras, efesien, disiplin, visioner, antisipatif, mampu menciptakan peluang baru, berani mengambil keputusan yang tepat sehingga memperkecil resiko, jujur dan terpercaya. (Adi Susanto, 2002: 12).

Jiwa kewirausahaan sebenarnya merupakan salah satu budaya nenek moyang bangsa Indonesia, sebagai contoh bangsa kita yang tinggal dinegeri kepulauan dapat mengembangkan usaha sampai ke Madagaskar dikala itu. Namun demikian jiwa kewirausahaan ini sempat dimatikan oleh penjajah yang menguasai bangsa Indonesia ratusan tahun dan diganti dengan jiwa "Amtenar" atau jiwa pegawai yaitu jiwa mengabdi kepada penguasa.

Beberapa pengertian tentang jiwa kewirausahaan. Menurut (Meredith, et al, 2005: 5) jiwa kewirausahaan adalah :

"Semangat, sikap dan watak yang dimiliki seseorang dalam melihat dan menilai kesempatan bisnis dan mengumpulkan sumberdaya guna mengambil keuntungan

P.ISSN: 1410-7988 E.ISSN: 2614-123X 
dan mengambil tindakan yang tepat guna memastikan sukses".

Dalam buku Small and Medium Enterprise Outlook 2000 (Paramita Parananingsih, 2001 : 27) bahwa jiwa kewirausahaan adalah :

"suatu naluri atas adanya kesempatan, suatu keberanian untuk mengambil resiko bisnis dengan mengembangkan sesuatu yang baru baik barang maupun jasa".

Batasan jiwa kewirausahaan tidak akan terlepas dari ciri atau indikator dari kewirausahaan yang akan dipakai sebagai alat ukur. Banyak konsep yang telah dikemukakan tentang ciri kewirausahaan, (Geoffrey Meredith, et.al, 2002: 5) mengatakan bahwa untuk mencapai keberhasilan usaha, wirausaha harus memiliki jiwa kewirausahaan dengan ciriciri dan watak kewirausahaan.

Pengertian dari ciri-ciri kewirausahaan tersebut adalah sebagai berikut :
1. Percaya diri
2. Pengambilan resiko
3. Kepemimpinan
4. Keorsinilan

\section{METODE}

Dalam penulisan ini penulis mengadakan penelitian langsung pada CV. Muda Jaya Mandiri yang berkedudukan di Teratak Buluh Kabupaten Kampar. Populasi adalah keseluruhan objek penelitian. Berkaitan dengan penelitian tersebut di atas, maka yang menjadi populasi adalah seluruh pelanggan CV. Muda Jaya Mandiri yaitu sebanyak 119 orang, dengan demikian jumlah sampel yang digunakan dalam penelitian ini dengan tingkat kepercayaan $10 \%$. Metode pengambilan Sampel penulis menggunakan metode acak sederhana (incidental random sampling) yaitu sebuah sampel yang diambil sedemikian rupa sehingga tiap unit penelitian dari populasi mempunyai kesempatan yang sama untuk dipilih sebagai sampel dalam penelitian ini. Jadi yang menjadi sampel yaitu sebanyak 54 responden dalam penelitian ini. (Husein Umar, 2003 : 146)

Eko dan Bisnis (Riau Economics and Business Reviewe) Volume 10, Nomor 4, 27 Desember 2019
HASIL

\section{Aspek Kewirausahaan}

Kewirausahaan

adalah suatu aktivitas mencakup manusia yang membangun suatu nilai dari sesuatu yang sebelumnya tidak mempunyai nilai, ia berusaha mencapai peluang-peluang berdasarkan sumberdaya-sumberdaya atas masing-masing sumberdaya yang dimilikinya. Ia memerlukan suatu visi dan kesabaran serta komitmen untuk mengajak orang lain untuk mencapai visi tersebut. Ia juga memerlukan suatu kesediaan untuk mengambil risiko yang diperhitungkan.

Kewirausahaan disebut sebagai suatu peroses kreatifitas yang desdruktif. Dimana wirausaha secara terus menerus berupaya mengganti atau memusnahkan produk yang ada atau metode produksi dengan sesuatu yang baru.

Tabel: Rekapitulasi Perkembangan

Jumlah Unit Usaha yang Berdiri dan Pailit pada Usaha pakan Ternak di Kab. Kampar Tahun 2014- 2018

\begin{tabular}{|c|c|c|c|c|c|c|c|c|c|c|}
\hline \multirow{3}{*}{$\begin{array}{c}\text { Prusahaan } \\
\text { pakan } \\
\text { ternak }\end{array}$} & \multicolumn{10}{|c|}{ Perkembangan Jumlah Unit Usaha Yang Berdiri dan pailit } \\
\hline & \multicolumn{2}{|c|}{2014} & \multicolumn{2}{|c|}{2015} & \multicolumn{2}{|c|}{2016} & \multicolumn{2}{|c|}{2017} & \multicolumn{2}{|c|}{2018} \\
\hline & Berdiri & Pailit & Berdiri & Pailit & Berdiri & Pailit & Berdiri & Pailit & Berdiri & Pailit \\
\hline \multirow{2}{*}{$\begin{array}{l}\text { Jumlah } \\
\text { (unit) }\end{array}$} & 25 & 2 & 23 & 1 & 25 & 2 & 23 & 5 & 35 & 2 \\
\hline & \multicolumn{2}{|c|}{23} & \multicolumn{2}{|c|}{22} & \multicolumn{2}{|c|}{23} & \multicolumn{2}{|c|}{18} & \multicolumn{2}{|c|}{33} \\
\hline
\end{tabular}

Sumber: Dinas Perdagangan dan Perindustrian Kab. Kampar, 2019

Agar perusahaan dapat mempertahankan dari kepailitan seperti yang terlihat dari tabel diatas seharusnya perusahaan harus lebih memperhatikan halhal yang menunjang akan keberhasilan dan dapat mengembangkan usaha untuk lebih maju lagi, maka perusahaan harus lebih memperhatikan faktor-faktor yang mempengaruhi kewirausahaan dan jiwa kewirausahaan diantaranya perusahaan harus memperhatikan pada aspek kewirausahaan yang akan digunakan untuk perkembangan pada perusahaan pengelolaan pakan ternak pada CV. Muda Jaya Mandiri.

Sedangkan jawaban dari pertanyaan yang penulis ajukan untuk pimpinan $\mathrm{CV}$. Muda Jaya Mandiri sekitar variabel

P.ISSN: 1410-7988 E.ISSN: 2614-123X 
keberhasilan usaha dan aspek kewirausahaan adalah sebagai berikut :

\section{Variabel keberhasilan usaha}

1. Bagaimana perkembangan akumulasi modal pada usaha pakan ternak yang bapak pimpin sekarang ini ?

Kalau saya lihat perkembangan modal cukup meyakinkan sebab dalam masa beberapa tahun saja modal awal yang dikeluarkan untuk membuka usaha ini sudah kembali. Jadi untuk perputaran modal usaha ini biasanya diputarkan kembali untuk membeli bahan baku dan untuk biaya operasional serta untuk penambahan peralatan perusahaan.

2. Bagaimana dengan produksi, apakah dalam masa lima tahun ini terus mengalami kenaikan pada perusahaan Bapak?

Ya, karena kami memproduksi pakan ternak ini disesuaikan dengan permintaan pasar. Perkembangannya sangat signifikan seperti pada awal usaha pakan ternak ini hanya memproduksi sekitar $200 \mathrm{~kg}$ dalam satu hari sekarang sudah mencapai 1 ton dalam satu harinya.

3. Bagaimana perluasan usaha, apakah perusahaan Bapak ada membuka cabang selain perusahaan CV. Muda Jaya Mandiri ini ?

Saat ini kami sudah membeli lahan didaerah Tibun untuk membuka cabang disana khususnya menyediakan pakan ternak untuk ikan patin. Kami memilih daerah disana karena banyak masyarakat yang beternak ikan patin.

4. Apakah dalam masa lima tahun terakhir ini perusahaan mengalami penambahan sarana fisik seperti penambahan gudang dan lain-lain ?

Saat ini kami ada menambah 1 unit mesin pengolahan pakan ternak yang daya produksinya 1 ton/jam, dan saat ini kami telah mampu membuat 2 gudang yang masing-masingnya untuk menyimpan bahan baku mentah dan bahan pakan yang sudah jadi.

Eko dan Bisnis (Riau Economics and Business Reviewe) Volume 10, Nomor 4, 27 Desember 2019
Dengan demikian untuk dapat lebih mengembangkan lagi pengembangan usaha maka perusahaan perlu mempertahankan apa yang telah diperoleh dalam masa lima tahun terakhir ini seperti pada akumulasi modal, produksi, perluasan usaha dan penambahan sarana fisik sangat memuaskan bagi pemilik usaha pakan ternak ini dan sesekali pihak perusahaan dapat mengambil langkah-langkah untuk menambah pengembangan usaha sepertinya pemilik mengeluhkan pada alat transportasi yang mana dalam hal ini pihak perusahaan dalam operasional masih menggunakan alat transportasi (pick up) dengan menyewa. Sepertinya pada alat transportasi sangat mempengaruhi pemilik dalam mengembangkan usaha jadi untuk akumulasi modal perusahaan harus memperhatikan pada alat transportasi yang sangat dibutuhkan oleh perusahaan untuk operasional perusahaan.

\section{Aspek Kewirausahaan}

1. Bagimana perkembangan/keberhasilan usaha dalam penjualan pakan ternak dalam lima tahun terakhir, apakah terus meningkat?

Adalah perkembangannya sedikitsedikit setiap tahunnya, tetapi jika dibandingkan dari awal perintisan usaha ini sampai saat sekarang sungguh luar biasa perkembangannya

2. Menurut Bapak, apakah dengan adanya percaya diri yang kuat dan memiliki keyakinan akan kemampuan bisa mencapai keberhasilan dalam berusaha ?

Tentu, keberhasilan usaha ini bisa dicapai karena saya mempunyai rasa percaya diri yang kuat

3. Sebelum memulai usaha, apakah Bapak sudah memikirkan resiko yang akan dihadapi di masa yang akan datang ?

Resiko apapun yang saya hadapi, saya tidak pernah cemas karena saya selalu mempersiapkan segala sesuatunya agar resiko yang saya hadapi kecil

4. Menurut Bapak, apakah semua wirausaha di tuntut untuk memiliki

P.ISSN: 1410-7988 E.ISSN: 2614-123X 
sifat kepemimpinan, dalam mencapai keberhasilan?

Tentu, sebagai pelaku usaha mesti memiliki sifat kepemimpinan.

5. Bagaimana dengan sifat keorsinilan (kreatif, inovatif dan fleksiblitas), apakah sifat tersebut harus dimiliki setiap wirausaha apabila ingin menjadi wirausaha yang sukses?

Harus punya sifat keorisinilan kalau tidak usaha ini tidak berkembang sama sekali.

Dengan demikian untuk dapat lebih mengembangkan lagi dari segi aspek kewirausahaan maka tidak ada salahnya pihak perusahaan mengambil langkahlangkah yang dapat diterapkan pada usahanya untuk menutupi kekurangan dari pihak perusahaan yaitu :

1. Tidak ada salahnya jika untuk bisa lebih mengembangkan keberhasilan usaha pihak perusahaan mengambil langkah mempromosikan hasil produksinya pada media cetak maupun elektronik agar konsumen lebih mengetahui keberadaan pakan ternak yang diproduksi olah CV. Muda Jaya Mandiri.

2. Untuk mengurangi tingkat resiko yang dihadapi perusahaan yang akan menyebabkan perusahaan menjadi pailit, pihak perusahaan harus memperbaiki kualitas produknya agar menjadi lebih baik minimal mempertahankan kualitas produk yang sudah ada pada produk yang dihasilkan oleh perusahaan.

3. Dari segi distribusi, tidak ada salahnya jika perusahaan mencoba memasarkan produk pakan ternaknya dengan menggunakan pedagang penyalur, karena dengan menggunakan pedagang penyalur maka penjualan produk pakan ternak CV. Muda Jaya Mandiri akan lebih meningkat, Hal ini mengantisipasi kecendrungan masyarakat/konsumen yang lebih suka membeli produk yang mudah dijumpai di pasaran.

Dengan langkah-langkah diatas diharapkan dapat lebih meningkatkan penjualan produk pakan ternak pada $\mathrm{CV}$. Muda Jaya Mandiri. Oleh karena itu pihak

Eko dan Bisnis (Riau Economics and Business Reviewe) Volume 10, Nomor 4, 27 Desember 2019 perusahaan selain memperhatikan produk yang dihasilkan, harga yang ditetapkan dan promosi juga hendaknya dapat betul-betul memperhatikan masalah distribusi. Selain itu jiwa kewirausahaan bagi pemilik juga menjadi motivator dalam mencapai keberhasilan perusahaan dengan jiwa kewirausahaan maka ada kemungkinan besar apa yang diharapkan dari usaha ini akan memberikan hasil yang memuaskan.

\section{SIMPULAN}

Berdasarkan hasil penelitian dan pembahasan yang telah penulis kemukakan pada bab sebelumnya, maka dapat ditarik beberapa kesimpulan diantaranya :

1. Terjadinya fluktuasi penjualan produk pakan ternak pada CV. Muda Jaya Mandiri, sehingga target penjualan tidak tercapai, hal ini berhubungan erat dengan aspek pemasaran dan aspek kewirausahaan

2. Strategi produk yang terdapat pada produk pakan ternak tercermin dan muncul melalui kualitas (merek, kekuatan dan ketahanan) yang diberikan dimana ini merupakan pertimbangan konsumen sebelum memutuskan untuk melakukan pembelian.

3. Harga merupakan pertimbangan utama bagi konsumen sebelum memutuskan untuk melakukan pembelian. Kebijakan harga yang dilakukan oleh CV. Muda Jaya Mandiri dirasakan masih biasabiasa saja dibandingkan produk sejenis.

4. Kegiatan promsi untuk mendukung pemasaran produk pakan ternak oleh CV. Muda Jaya Mandiri dapat berupa periklanan (surat kabar, brosur, spanduk, personal selling (tenaga penjual, sales counter) dan promosi penjualan (discount dll).

Dari segi aspek kewirausahaan pemilik CV. Muda Jaya Mandiri telah mengalami peningkatan pendapatan selama periode penelitian selain itu pemilik perusahaan selain mempunyai pengalaman dibidang pengolahan juga 
memiliki pengetahuan yang luas mengenai jiwa kewirausahaan.

\section{DAFTAR RUJUKAN}

Benedicta Prohatin Dwi Riyanti, 2003. Kewirausahaan Dari Sudut Pandang Psikologi Kepribadian, Edisi Pertama, PT. Grasindo, Jakarta.

E. Jerome MC. Charty, (Terjemahan oleh Gunawan Hutauruk MBA), Dasardasar Pemasaran, Erlangga, Jakarta. 2000.

Halim Herman Edyanus, 2002, Menjadi Wirausahawan Handal, Bahana Press, Pekanbaru

Kotler Philip. 1998, Manajemen Pemasaran, Analisis, Perencanaan Implementasi dan Kontrol, Edisi Revisi Jilid 2, 1998. 2003, Manajemen Pemasaran Edisi kesebeas, jilid 1, penerbit PT Indeks Kelompok Gramedia,

Meredith, Geoffry G.et al, Penerjemah Andre Aspasayogi, 2002., Kewirausahaan teori dan praktek. PT. Pustaka Binaman Pressindo, Jakarta.

Marnis, 2007., Pengantar Bisnis, Penerbit Unri Press, Pekanbaru.

Moezamil Zamahsari., Pemasaran Internasional Intermedia, Jakarta 1995.

Nitisemito, Akex S. B. Marketing, Jakarta: Ghalia Indonesia,1996

Puji Lestari, Sri Indarti, 1999, Pengukuran Konerj Koperasi, "Studi Kasus Pada Koperasi Pegawai Departemen Koperasi dengan pendekatan Balanced Scorecard, Tesis Pascasarjana UI, Jakarta (Tidak dipublikasikan).

Robert D. Hisrich, dkk, 2008., Entrepreneurship Kewirausahaan. Penerbit Salemba Emat, Jakarta.

Siagian. P. Sondang., Manajemen Strategi, Penerbit Bumi Akasara, Jakarta, 1995.

Swastha, DH. Basu. Azas-Azas Marketing. Yogyakarta: Liberty, 1996.

\section{Saluran Pemasaran.}

Yogyakarta: FE-UGM, 1997.

Sutejo Siswanto. Karangka Dasar Manajemen Pemasaran. Jakarta: PT. Binaan, 1996.

Eko dan Bisnis (Riau Economics and Business Reviewe) Volume 10, Nomor 4, 27 Desember 2019
Suryana, 2003. Kewirausahaan, Edisi Revisi, Selemba Empat, Jakarta.

Soeharto, Prawirokusumo, 1999, Kewirausahaan dan Usaha Kecil, Lembaga Perekonomian Nahdatul Ulama, Jakarta.

Suwandi, 2000., Faktor-faktor yang Mempengaruhi Kualitas Kewirausahaan dan Hubungannya dengan Kinerja Usaha, Disertasi Pascsarjana Unpad (tidak dipublikasikan

Siswanto, H.B, 1994, Pengantar Manajemen, Jakarta, Penerbit PT. Bumi Aksara

Umar, Husein, 2003, Riset Pemasaran dan Perilaku Konsumen, PT. Gramedia Pustaka Utama, Jakarta.

William J. Satanton. Perinsip Pemasaran, Edisi VII, Alih Bahasa Sudu Sundaru, Jakarta: Erlangga, 1997.

Winardi. Manajemen Pemasaran. Bandung: Sinar Baru, 2000.

Zimmerer,W. Thomas, Norman, M Scarborought, 2002. Pengantara Kewirausahaan dan Manajemen Bisnis Kecil, Alih Bahasa Yanto Sidik pratiknyo dan Edina Tjahyaningsih, prenhallindo, Jakarta. 